\title{
The Role of Marketing and Individual Environment Association in Elevating the Customer Value
}

\author{
Rahayu Kusumadewi \\ Lecturer of Public Administration Department, Faculty of Social and Political Sciences, Islamic State \\ University of Bandung, Indonesia \\ rahayukusumadewi@yahoo.com
}

\begin{abstract}
This research aimed at descriptively reviewing marketing and individual environment association upon the customer value as well as verifying the influence of the association upon the customer value, both in partial and simultaneous measurements. A descriptive verification method was applied to the research. Furthermore, the population of the research consisted of students who had been officially registered at Faculty of Teacher Training and Education conducted by Private Universities in West Java Province. A proportional cluster random technique was used to select the sample. In terms of data sources, there were two types: primary and secondary data. To analyze the data, an analysis of Structural Equation Modelling (SEM) was occupied. The result of the research had indicated that marketing and individual environment association and the customer value had shown unsatisfactory outcome. According to verification research, marketing and individual environment association had significantly contributed to the customer value, both in partial and simultaneous measurements.
\end{abstract}

Keywords: Marketing; individual environment; customer value.

\section{Introduction}

Private universities are units of higher education under the management of private sectors. Referring to the Law of 2012 No. 2 about Higher Education, private universities are established and/or conducted by a group of society through a formation of a law-referenced board under a non-profit principle. In this 4.0 industrial era, private universities have been struggling harder to get involved and to give pressure upon their counterparts within tight competition, especially in terms of technological advance. It indicates that by means of technology, the universities have been equipped with more advanced excellence. Giving added value to the students is also supposed to positively influence the position and prestige of the universities that they actually are in level with, even better than, other universities. The customer value can be triggered by some factors related to association, i.e. marketing and individual environment, which provide support or motivation to use the service as expected. Revisiting previous research, it had been empirically reviewed that marketing association and customer value constituted two essential factors, especially in the context of service industries (Hanaysha 2017); (Thalib 2015); and (Wu and Li 2018). Individual environment, referring to this research, is strongly related to individual strength in defining their own choices on the bases of culture, social, status, and psychology, which later can be referred to as a strong motivation in making decision upon the best choice or product/service (Amirullah 2002). On the other hands, the influence of individual environment stems from external sphere consisting of people with a positive view on particular product or service they had used (Kotler, Philip dan Amstrong 2014).

Regarding the background, this research considers the customer value as an important element for an industry, both in service and manufacture. Moreover, the maximum customer value can be made only if positive influence of marketing and individual environment association does exist. For that reason, this research is intended to empirically review the 
marketing and individual environment association in a relationship to the customer value in addition to investigating the effect of the association upon the customer value, in simultaneous and partial measurements.

\section{Literature Review}

\subsection{Marketing Association}

Understanding of symbolic interaction is a way of thinking about mind (mind), self and society that has contributed to the sociocultural tradition in building communication theory. By using sociology as a foundation, this notion teaches that when humans interact with each other, they share meaning for a certain period of time and for certain actions (Saleh, et. al, 2018). Service marketing association refers to a set of marketing means used to achieve the marketing goals within the target market, comprising product, price, promotion, place, people, physical evidence and process of which all variables involved are controllable by a particular organization or board for the sake of competitive advantage (Haksever et al 2000); (Kotler 2016). (Buchari Alma 2016) suggested that service marketing association covers product, price, promotion, place, people, physical evidence and process. This is also supported by (Hurriyati 2010) claiming that service marketing association refers to a concept on traditional marketing association which has $4 \mathrm{P}$ as highlight, i.e. product, price, place, and promotion, extended with supplementary elements non-traditional, such as people, physical facilities, and process, transforming to 7P. The term 'individual' is originated from the word 'individuum' which means 'undividable'. The implementation of marketing strategy as reported by (Nuseir and Madanat 2015) would end in a positive impact to the customers, as long as the procedures meet the standards. The similar result was also reported by (Londhe 2014) which showed that marketing association was referred to an instrument for marketing and deemed to have a positive impact upon the enhancement on the customer value.

\subsection{Individual Environment}

The term 'individual' refers to addressing the smallest and most limited part. The term does not necessarily mean that human as the whole remaining undividable, but rather as the limited whole as a single person (Abu Ahmadi 2003). Referring to the lexical meaning, individual is defined as a person, a character (separated from others), which is physiologically defined as being so free that no organic relationship with people around occurs (Alwi 2002). Alluding to the concept, individual can be meant as a state or condition that physiologically entails a person. Thus, individual factor related to customer behavior can be described as a strength remarking the customers as individuals which might influence the customer value. The entailing strength on the customers individually is deemed as individual factors or characteristics that personify the customers. (Amirullah 2015) commented that the individual strength consisted of learning and memory, personality and self concept, motivation and involvement, attitude, and life style.

\subsection{Customer Value}

(Barnes 2003) proposed the importance of customer value concept to achieve the marketing success. The value perceived by the customers is said as the stepping stone and triggering factor to achieve the customer satisfaction. The most fundamental issue in need of complex understanding in order to attract and keep the customer trust is to know how to 
establish a value creation and to add value the customers are provided with. Without a serious understanding on the concept of value creation, it will be much more difficult to elevate the marketing target through repetitive purchase made by the customers. Furthermore, (Haksever et al 2000) defined: "Value is the ability of goods or service to satisfy a need or benefit to a customer". (Kotler 2012) suggested that: "Customer perceived value is the difference between the prospective customer's evaluation of all benefits and all costs of an offering and perceived alternatives. Total customer value is the perceived monetary value of the bundle of economic, functional and psychological benefit customer expect from a given market offering product. Total customer cost is the bundle of cost customer expect to incur in evaluating, obtaining, using and disposing of the given market offering. (Kotler 2016) denoted that the value perceived by the customers could be the gap between total customer value and total customer cost. Total customer value is defined as a collection of benefits expected by the customers upon the product or service they have purchased. Meanwhile, total customer cost is meant as a collection of risks appraised by the customers to exist when they evaluate, receive, and make use of the product or service. The perceived value will be a lifetime experience to the customers and a cause whether they make repeated purchase or move to other products or services. The customer value is the key to expanding the probability to win the market (Mcfarlane 2013), as with the superior value, positive influence on the customer satisfaction and loyalty will occur (Sugiati et al. n.d.); (Surydana 2017).

\subsection{Construct Framework}

The performance of marketing association is considered to possess a strong function in forming an image upon the customers despite the limitation for value formation in customers' points of view. For that reason, the administration of marketing association is influenced by individual factor which is strongly effective to positively affect the value of the service (Prabowo and Nusantara 2005). Some studies had indicated a quite strong influence of marketing association upon the customer value (Bachtiar Hasibuan, Suherly,Umi Kaltum 2015; Hanaysha 2017). Meanwhile, there is a study (Ekrem Cengiz 2007) that had shown that marketing association would be more significant if individuals involved as the agents who were supposed to give a positive impression, expressed among others (the customers). Further, a research (Romdonny et al. n.d.) had indicated that the customer value could be achieved optimally only if there was a support from marketing association performance. 


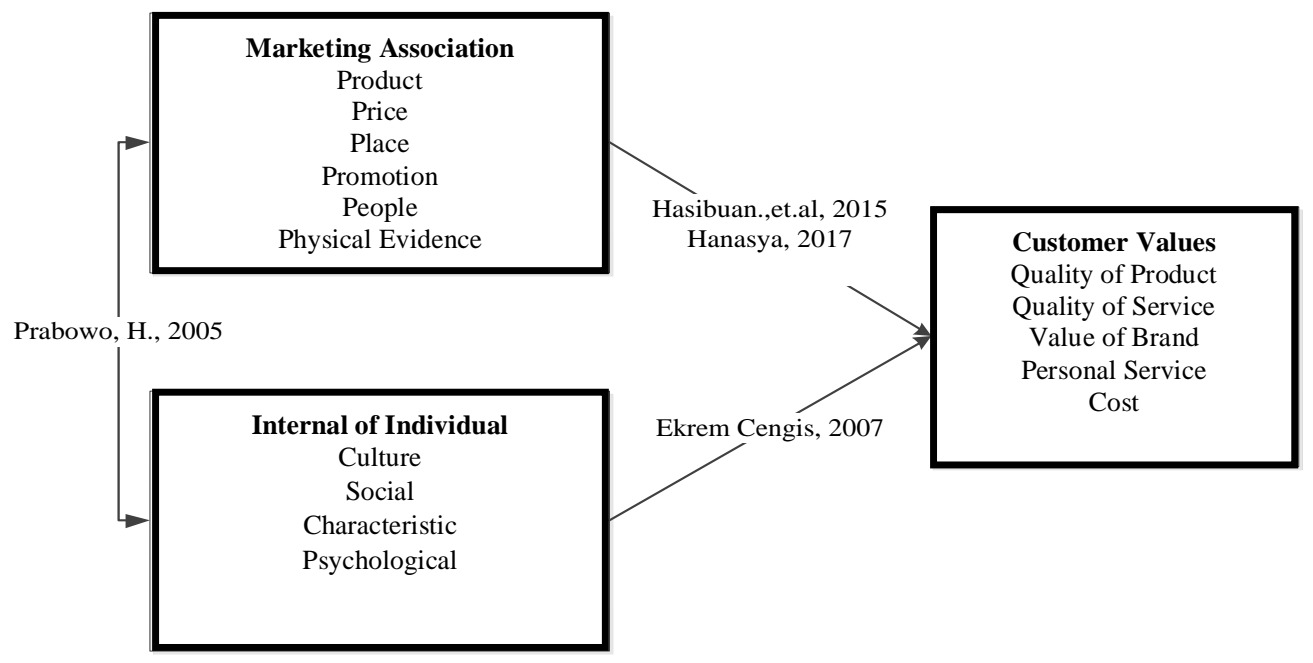

Figure 1. The Research Paradigm

\section{Research Methods}

This research actually dealt with human resource management, specifically on educational context. The method used was explanatory survey, referring to associating and to examining all the variables involved. This research, moreover, was conducted in private universities in West Java Province, with the students from the Faculty of Teacher Training and Education as the center of analysis. Data collected would consist of primary and secondary data. The primary was referred to the result of questionnaire covering a number of questions the students had to answer and also to the observational result on research objects. Meanwhile, the secondary was reflected from documentation or reports with reference to the observed objects collected from the universities in the field of Faculty of Teacher Training and Education in West Java Province along with the guidelines issued by each of the engaged universities. The unit of analysis in this current research comprised the whole students who had been officially admitted to private universities in the field of Teacher Training and Education in West Java Province. All of them were the respondents supposed to perceive the marketing association, individual environment, and customer values based on the result of evaluation in selecting private university on the Faculty of Teacher Training and Education as an evaluative consideration for an in-depth review, aiming at elevating the quantity of prospective students. Proportional random sampling technique was used to define the research sample, taken from the population proportionally, so that each of sampling units within the population could represent the population itself.

Table 1. The Research Respondents

\begin{tabular}{|l|r|r|}
\hline \multicolumn{1}{|c|}{ Higher Education (Universities) } & \multicolumn{1}{|c|}{ Total } & \multicolumn{1}{|c|}{ Sample } \\
\hline Bandung & & \\
\hline - Advent University of Indonesia & 87 & 1 \\
- Pasundan University & 3,082 & 45 \\
- Langlang Buana University & 179 & 3 \\
- Nusantara Islamic University & 2,147 & 32 \\
\hline Cirebon & & \\
\hline
\end{tabular}




\begin{tabular}{|l|r|r|}
\hline$-\quad$ Unswagati & 1,975 & 29 \\
\hline Bogor & & \\
\hline$-\quad$ Pakuan University & 2,906 & 43 \\
$-\quad$ Ibn' Khaldun University & 966 & 14 \\
\hline Tasikmalaya & 1,654 & 24 \\
\hline$-\quad$ Siliwangi University & & 42 \\
\hline Majalengka & 2,851 & \\
\hline$-\quad$ Majalengka University & & 23 \\
\hline Kuningan & 1,563 & \\
\hline$-\quad$ Kuningan University & & 14 \\
\hline Indramayu & 971 & $\mathbf{2 7 0}$ \\
\hline$-\quad$ Wiralodra University & $\mathbf{1 8 , 3 8 1}$ & \\
\hline Total & &
\end{tabular}

Source: compiled from some literatures

Among 18,381 students, only 270 of whom were selected and recruited as the research sample by means of Isaac and Michael formula with degree of error that signified 5\% (Sugiyono 2008). Therefore, alluding to the paradigm shown above, Structural Equation Modeling (SEM) analysis was used to examine the hypothesis. In fact, this research was aimed at examining and analyzing causal relationship between exogenous and endogenous variables, including interfering and dependent endogenous, as well as entirely testifying the validity and reliability of the research instruments.

\section{Discussion}

The result and discussion of this research, both in descriptive and verification forms, were elaborated in the following table and figure:

Table 2. The Result of Descriptive Analysis on Research Variables

\begin{tabular}{|l|c|c|c|l|}
\hline \multicolumn{1}{|c|}{ Variables } & $\begin{array}{c}\text { Average } \\
\text { Scores }\end{array}$ & $\begin{array}{c}\text { Deviation } \\
\text { Standard }\end{array}$ & Ranges of Scores & Categories \\
\hline $\begin{array}{l}\text { Service Marketing } \\
\text { Association }\end{array}$ & 3.630 & 0.992 & $2.638-4.622$ & $\begin{array}{l}\text { Good - } \\
\text { Excellent }\end{array}$ \\
\hline Individual Environment & 3.394 & 1.094 & $2.300-4.488$ & $\begin{array}{l}\text { Less - } \\
\text { Excellent }\end{array}$ \\
\hline Customer Value & 3.746 & 1.064 & $2.682-4.810$ & $\begin{array}{l}\text { Good - } \\
\text { Excellent }\end{array}$ \\
\hline
\end{tabular}

Source: Research Data Processing - Collated

The result indicated in Table 2 had shown that marketing program administration involved some elements, such as product, price, place, promotion, people, and physical evidence. In addition, the process run by the universities to accommodate all of needs in Faculty of Teaching Training and education was considered 'good' to 'excellent'. Moreover, the analysis on individual environment consisted of cultural, social, personal, and psychological. Most of which had been perceived from 'less' to 'excellent' by the respondents upon their choices on private university at Faculty on Teacher Training and Education. The percentage of respondents' assessment in perceiving 'less' on individual 
environment signified $3.726 \%$. Another finding had also shown that individual environment constituted one of several factors to influence the individuals in selecting universities. The low perception on the judgement upon the selection of faculty offered had shown that the universities were considered less effective and optimum to meet the expectation of prospective students. Furthermore, the research had shown that the quality of product, service, personnel, image, and price was perceived from 'less' to 'excellent' by the respondents upon the universities at Faculty of Teacher Training and Education. Despite the fact, there were a number of respondents giving their perception from 'less' to 'very poor' with the percentage of $4.166 \%$. This finding had proved that not all of the respondents received the values provided by the universities since the values were not best-fitted to what they actually expected, specifically in terms of service given by the administrative sections of the universities, which was considered less optimum, both in knowledge and capacity, in managing all information the students might need.

Further analysis was centralized to structural models of research that existed by highlighting the coefficient values of existing relationship from each of the models. In this analysis, some indicator values of Fit Indexes models would be shown as the output of LISREL. In SEM analysis, Goodness of Fit Measures (GOF) was investigated, to see if the models had met the criteria of GOF. Thus, it could be said that the models established from the comparison between data and models were good. The criteria are shown as follows:

Table 3. The Criteria of Fit Indexes

\begin{tabular}{|l|c|c|}
\hline \multicolumn{1}{|c|}{ GOF Size } & Estimation & Result \\
\hline Statistic Chi-Square $\left(\mathrm{X}^{2}\right)$ & 409.303 & Fit \\
\hline P-Value & 0.000 & Fit \\
\hline Non-Centrality Parameter (NCP) & 255.226 & Fit \\
\hline Goodness-of-fit Index (GFI) & 0.870 & Fit \\
\hline Root mean square error of approximation (RMSEA) & 0.0707 & Good Fit \\
\hline Expected cross-validation index (ECVI) & 1.915 & Good Fit \\
\hline $\begin{array}{l}\text { Tucker-Lewis Index (TLI) or Non-Normed Fit Index } \\
\text { (NNFI) }\end{array}$ & 0.936 & Good Fit \\
\hline Normed Fit Index (NFI) & 0.904 & Good Fit \\
\hline Adjusted Goodness of Fit Index (AGFI) & 0.836 & Fit \\
\hline Incremental Fit Index (IFI) & 0.944 & Good Fit \\
\hline Comparative Fit Index (CFI) & 0.944 & Good Fit \\
\hline Parsimonious Goodness of Fit (PGFI) & 0.689 & Fit \\
\hline Parsimonious Normed Fit Index (PNFI) & 0.787 & Fit \\
\hline
\end{tabular}

Sources: The Output of Lisrel 8.5

The result of fit indexes measurement had shown that the models occurring had been fitted to the criteria of GOF. Further, the result of GOF had indicated that the model of influence on marketing and environmental association upon customer value was the good one to illustrate the relationship between observed variables. 


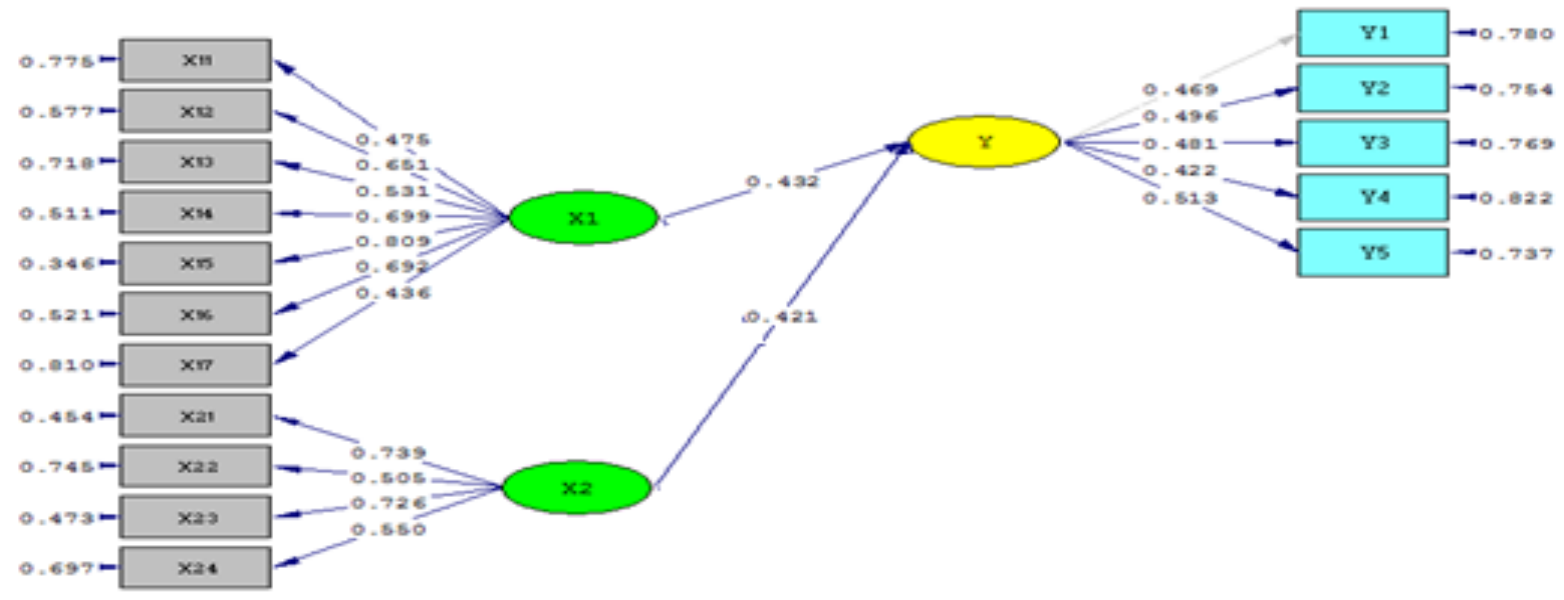

Source: The Output of Lisrel 8.5

Figure 2. The Result of SEM Analysis

The structural model of Figure 2 indicated the relationship between marketing and individual environment upon the customer value, implied in the following hypothesis: that marketing and individual environment association significantly and jointly influenced the customer value, both in partial and simultaneous measurements. With reference to the data processing through LISREL data program, the structural model shown in Figure 2 was bestfitted to the proposed hypothesis as follows:

$$
\begin{aligned}
& \mathrm{Y}=0.432 * \mathrm{X} 1+0.421 * \mathrm{X} 2 \text {, Error var. }=0.331, \mathrm{R}^{2}=0.669 \\
& (0.184)(0.188)(0.125) \\
& 2.348 \quad 2.240 \quad 2.654
\end{aligned}
$$

The result of measurement showed that customer value was influenced by marketing and individual environment association, both in partial and simultaneous measurements. According to correlation value and coefficient path from the measurement through Lisrel 8.5, the direct and indirect influences of marketing and individual environment association were

\begin{tabular}{|c|c|c|c|c|}
\hline \multirow[b]{2}{*}{ Variables } & \multirow{2}{*}{ 异 } & \multicolumn{2}{|c|}{$\begin{array}{c}\begin{array}{c}\text { Indirect Influence } \\
\text { through }\end{array} \\
\end{array}$} & \multirow{2}{*}{ 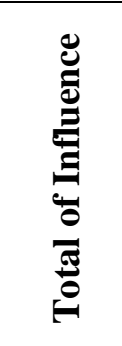 } \\
\hline & & 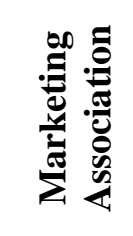 & 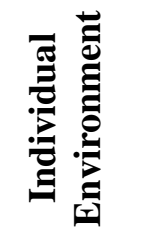 & \\
\hline Marketing Association & $18.7 \%$ & & $15.2 \%$ & $33.9 \%$ \\
\hline $\begin{array}{l}\text { Individual Environment } \\
\text { Association }\end{array}$ & $17.8 \%$ & $15.2 \%$ & & $33.0 \%$ \\
\hline Total & $36.5 \%$ & $15.2 \%$ & $15.2 \%$ & $66.9 \%$ \\
\hline
\end{tabular}
quite identifiable upon customer value as follows:

Table 4. The Direct and Indirect Influences

Source: Data processed through SEM. 
With reference to above table, it is evident that there were two kinds of influences yielded by marketing and individual environment association upon customer value, i.e. direct and indirect. The direct influence of marketing association upon customer value signified $18.7 \%$, while the individual environment upon customer value did on $15.2 \%$. Therefore, the accumulative influence of both variables, direct combined to indirect influences, upon customer value signified 33.9\%. Moreover, individual environment constituted a variable in this model that gave both types of influences, direct and indirect, upon customer value, with consecutively $17.8 \%$ and $15.2 \%$ through marketing association. By then, the accumulative influence of individual environment on customer value constituted $33.0 \%$. The result of the research had shown that, simultaneously, there was a positive and significant influence of marketing and individual environment association. The result of analysis was reflected by the determinant coefficient value that constituted $66.9 \%$. It denoted that customer value was quite high if supported with an accurate delivery of marketing program and an understanding on student's individual environment. Both of the variables were similar in influencing customer value. The difference took place at how marketing association could slightly overpower individual environment. The greater influence resulted in by marketing association had indicated the urgency of applying the construct of service marketing association on the context of universities in order to bring about meaningful benefit to customers about a number of programs that had been designed by the institutions, through associating product, price, place, people, physical evidence, and process elements. This was in line with (Zeitahml 2003) that the association of marketing, consisting of marketing interrelated elements, would be associated, organized, and accurately used, so that the institution can achieve the goals of marketing effectively, in addition to meet the customer satisfaction and expectation. The existence of positive influence from service marketing and individual environment association was in line with a research conducted by (Ghoni n.d.), indicating that environmental factor had influenced customer behaviors. The behaviors, stated in the research, referred to value receival by the institutions. Further, another research from (Ujang Muhyidin 2008) also supported the result of previous research, that individual environment of students and the performance of marketing association had significant impact to students' decision through added value meant to the students.

\section{Conclusion}

Marketing association committed by universities in West Java Province was considered less optimum. This was referred to the result of investigation, finding out that most of respondents showed negative and even strongly negative perception, especially on the indicator of closeness from students' boarding house to the campus area. Such an indicator was the lowest average among other indicators. Individual environment could affect the respondents' perception in receiving customer value from the universities, which was considered less optimum. The phenomenon occurred due to unpleasant to strongly unpleasant perception upon the universities. The finding related to less optimum individual environment affecting the respondents' behaviors was that the respondents were less positive upon the choice on faculty offered. The indicator of choice on faculty offered by the universities constituted the lowest standard of answer compared to its other counterparts under the context of individual environment. The value of benefit received by the respondents upon the 
universities in West Java Province was considered less optimum. This result was reflected from the fact that the respondents had quite negative perception on the capability, skill, and knowledge owned by the administrative sections, primarily related to information system that could meet what students actually expected.

Moreover, the result of verification research had shown that marketing and individual association had significant impact to customer value, both in simultaneous and partial measurements. The significance of each was considered quite representative in explaining customer value. Meanwhile, the influence of marketing association was shown greater than that of individual environment. Therefore, the verification research had uncovered that marketing and individual environment association influenced customer value, both in simultaneous and partial measurements. In addition, the significance of each was also deemed demonstrative to illustrate customer value. Meanwhile, marketing association had greater impact than that of individual environment one

\section{References}

Ahmadi, A. (2003). Psikologi Umum. Jakarta: Rineka Cipta.

Alwi. (2002). Kamus Besar Bahasa Indonesia. Balai Pust. Jakarta.

Amirullah. (2002). Perilaku Konsumen. Cetakan Pe. Jakarta: Graha Ilmu. (2015). Pengantar Manajemen. Jakarta: Mitra Wacana Media.

Barnes, J. G. (2003). Secret of Customer Relationship Management (Rahasia Manajemen Hubungan Pelanggan). Yogyakarta: Andi.

Buchari, A. (2016). Manajemen Pemasaran Dan Pemasaran Jasa. Bandung: Alfabeta.

Cengiz, E., and Yayla H., E. (2007). "The Effect of Marketing Mix on Positive Word of Mouth Communication: Evidence from Accounting Offices in Turkey." Innovative Marketing 3(4).

Ghoni, Abdul. "Pengaruh Faktor Budaya, Sosial, Pribadi Dan Psikologi Terhadap Perilaku Konsumen ( Studi Pada Pembelian Rumah Di Perumahan Griya Utama Banjardowo Semarang ) The Influence Of Factor Of Cultural, Social, Personality And Psychology On Customer Behavior Studies In Real Estate Main Griya Banjardowo Semarang." : 123.

Hasibuan, B., Suherly, Kaltum, U., and Septiadi. (2015). "Marketing Mix Performance on Customer Value and the Effect on Customer Trust and Customer Loyalty on Pt. Pindad (Persero) As the Army Defense Industry of Indonesia (A Survey on Customers)." International Journal of Management Sciences and Business Research 5(1).

Haksever, et. al. (2000). Service Management Operations. New Jersey: Pearson Pretince Hall.

Hanaysha, J., R. (2017). "An Empirical Examination of Marketing Mix Elements and Customer Perceived Value in Retail Industry." : 1-10.

Hurriyati, R. (2010). Bauran Pemasaran Dan Loyalitas Konsumen. Bandung: Alfabeta.

Kotler, P. and Amstrong, G. (2014). Principles of Marketing. 12th ed. New Jersey: Pearson Pretice Hall.

Kotler, P. and Keller, K., L. (2012). Marketing Management, 14th. 14th ed. New Jersey: Person Education.

- 2016. Marketing Managemen, 15th Edition. 15th ed. New Jersey: Pearson Education,Inc. 
Londhe, B R. (2014). "Marketing Mix for Next Generation Marketing." Procedia Economics and Finance 11(1964): 335-40. http://dx.doi.org/10.1016/S2212-5671(14)00201-9.

Mcfarlane, D., A. (2013). "The Strategic Importance of Customer Value Customer Value." 2(1).

Nuseir, Mohammed, T., and Madanat, H. (2015). "4Ps : A Strategy to Secure Customers ' Loyalty via Customer Satisfaction." 7(4): 78-87.

Prabowo, Harjanto, and Universitas Bina Nusantara. 2005. "Proses Keputusan Mahasiswa dan Nilai Jasa." : 23-24.

Romdonny, J., et al. "The Factors That Affect Customer Value and Its Impact on the Customer Loyalty." : 299-305.

Saleh, M. et al (2018) Chinese Ethnic Communication Pattern in the Environment of Indigenous People in Lhokseumawe, Indonesia. Budapest International Research and Critics Institute Journal, 1(4): pp. 7-16.

Sugiati, Tinik, Thoyib, A., Hadiwidjoyo, D., and Setiawan, M. "The Role of Customer Value on Satisfaction and Loyalty ( Study on Hypermart 's Customers ).” 2(6): 114-123.

Sugiyono. (2008). Metode Penelitian Kunatitatif Kualitatif Dan R\&D. Bandung: Alfabeta.

Surydana, L. (2017). "Service Quality , Customer Value and Patient Satisfaction on Public Hospital in Bandung District , Indonesia." 7(2): 187-92.

Thalib, S. (2015). "The Effect of Services Marketing Mix and Customer Value on Satisfaction, Trust , and Loyalty." 3(9): 935-49.

Muhyidin, U. (2008). "Pengaruh Bauran Pemasaran Jasa Pendidikan Terhadap Keputusan Mahasiswa Memilih Perguruan Tinggi Swasta Di Jawa Barat." In Prosiding Seminar Nasional Multi Disiplin Ilmu \& Call for Papers Unisbank (Sendi_U).

$\mathrm{Wu}$, Ya-ling, and Li, Eldon. (2018). "Marketing Mix , Customer Value , and Customer Loyalty in Social Commerce : A Internet Research Article Information :"

Zeitahml, VA. Bitner MJ. (2003). Service Marketing: Integrating Customer Focus Across the Firm. 3rd Editio. Boston: McGraw Hill/Irwin. 